\title{
The Theoretical Framework of Macroprudential Policy and its Place in the Scheme of Economic Policy
}

\author{
János Kálmán* \\ * Dr. János Kálmán, assistant lecturer, Department of Administrative and Financial Law, Faculty of Law, Széchenyi István University in \\ Győr. His main field of research is macroprudential policy in the context of administrative law. (e-mail: janos.kalman88@gmail.com)
}

Abstract: Microprudential regulation and supervision - focused on institutional risks - cannot guarantee the stability of the financial system. Therefore special attention should be paid to macroprudential regulation and supervision to address systemic risks. The purpose of this study is to provide the historical context and a theoretical framework for macroprudential regulation and supervision - a new area of economic policy. To this end, we shall examine the causes for the spread of macroprudential policy, its basic concepts, and thirdly, its place within the scheme of economic policies.

Keywords: economic policy; Glass-Steagall Act; macroprudential policy; regulation and supervision

\section{Introduction}

The liberalization and deregulation pervading the regulation of financial markets in recent decades would go hand in hand with a significant decrease in states' ability to intervene. Due to regulatory deficiencies, supervisory authorities were incapable of sensing the impending crisis and were also unable to handle aspects of the crisis that had been identified. Providing a new basis for the regulation of financial markets and simultaneously strengthening supervisory competencies have constantly been on the agenda since 2008: on the global level at the Financial Stability Board formed by the G20, on a regional level with the European Union, as well as at the state level. An agreement has been reached between those creating regulatory and supervisory policy, and academic representatives in that microprudential regulation and supervision that focus on institutional risks are insufficient for ensuring the stability of the financial system; therefore significant attention must be paid to macroprudential regulation and supervision that aim to handle systemic risks. This policy area practically did not even exist prior to 2008 and its conceptual definition, the development of its tools as well as its relationship to other areas of economic policy is still evolving. This study aims to present the historical and theoretical basis for macroprudential regulation and supervision as a new field of economic policy. To this end, we shall examine the causes for the spread of macroprudential policy, its basic concepts, and thirdly, its place within the scheme of economic policy. 1

\section{Reasons for the spread of the macroprudential approach}

The global economic crisis that emerged in 2008 - specifically an asset price-bubble 2 at the outset - was not the first serious setback in human history. One of the basic characteristics of the economy is that it is in constant change; sometimes it grows, other times it begins to decline 3 and this cyclicality is especially true for the workings of the financial markets. Based on broad empirical research, Leaven and Valencia demonstrated that of the 42 banking crises occurring between 1970 and 2007, 55\% were also followed by a currency crisis; in contrast, the number of sovereign debt crises was far lower; over half of bank crises were accompanied by another crisis (currency and banking crises). Furthermore, in almost $11 \%$ of cases, a triple crisis occurred (i.e. currency, banking, and sovereign debt crises simultaneously). 4 Distinct risks in particular economic sectors are thus able to have an effect on the stability of the whole sector, which - due to the interconnectedness of actors in the economy - may contaminate other sectors and thus the whole of the economy. Therefore it is worth briefly reviewing the reasons that led to the spread of macroprudential regulation and supervision in the financial markets.

\subsection{The Glass-Steagall Act}

The supervisory and regulatory side of the 'Great Depression' of 1929-1932 yielded numerous morals and consequences, the causes of which are to be found in the erosion of faith in the financial markets' flexibility and ability to self-regulate i.e. in the 'invisible hand' of the market according to Adam Smith. The Glass-Steagall Act 5 enacted in 1933 made an 
attempt - in order to restore faith in the banking system $\underline{6}$ - to restrict the propensity to speculate, which can be regarded as a basic aspect of financial markets. To this end - effectively erecting a firewall between the activities of financial institutions -, the Glass-Steagall Act separated commercial and investment banking activities. This fundamentally meant that if a bank accepted deposits, it could only use them for providing credit but was prohibited from trading on the stock exchange. The Act also introduced restrictions regarding the speculative use of capital, eliminated interest on deposits repayable on demand, introduced a deposit insurance scheme and the minimum capital requirement. $Z$ The fundamental aim of the Act was to prevent from hastily risking or at least seriously limit banks concerning the funds of depositors. Consequently, the Act also tried to refrain states - i.e. taxpayers - from having to bail out troubled financial institutions when they are near bankruptcy.

The Glass-Steagall Act placed emphasis on security, soundness, stability and avoidance of abuse amid steady growth rather than quick but risky growth; i.e. it targeted the creation of a system of safeguards providing protection against renewed financial crises. However, the regulations of the Glass-Steagall Act - through taking advantage of its deficiencies - were often worked around by market participants, and constantly eroded during their time in effect. $\underline{8}$ Firstly, the avoidance of the separation of functions appeared in the formation of foreign subsidiaries by financial institutions, since financial markets were significantly more deregulated in numerous jurisdictions - such as in Great Britain - than in the USA. Secondly, commercial banks developed new instruments for investment that behaved almost like securities, while investment banks developed products with the characteristics of loans and deposits, 2 as a result of which they essentially became each other's competitors. A fundamental new technique serving the 'avoidance' of the Glass-Steagall Act became available from the 70 s when banks began to sell 'repacked', in other words 'securitized' loans - initially of high quality to investors in the capital markets. 10 We call this the originate-to-distribute model. The essence of this practice lies in that banks are able to transform illiquid instruments into liquid ones having a large market, while the institution originally providing loans spreads its risk among investors.11

It must be stressed that - besides market actors - the central bank of the United States of America, the Federal Reserve System (hereinafter referred to as the Fed) itself played a crucial role in the decline of the Glass-Steagall Act's provisions incentivizing stability. Article 20 of the Act contained a general prohibition on banks' forming affiliations with companies whose principal activity is securities underwriting. However, the Fed reinterpreted this prohibition in such a way that initially $5 \%$, then $10 \%$, and after $1997,25 \%$ of the total revenues of commercial banks could originate from investment banking; 12 furthermore, in 1990 it expressly permitted J. P. Morgan \& Co. to underwrite securities. 13 Hence the Fed, in the words of Wolfgang Reinicke, de facto overruled the Glass-Steagall Act.14 This process resulted in the U.S. Congress having no other choice but - after several unsuccessful bills 15 - to formally remove the barriers between commercial and investment banking activity with the Gramm-Leach-Bliley Act of 1999.

\subsection{The consequences of the Gramm-Leach-Bliley Act}

Uncovering the causes of the global economic crisis of 2008 is not an aim of this study, 16 however, it is necessary to point out that restrictions removed by the Gramm-Leach-Bliley Act in the spirit of - 'cyclical euphoria' 17 - created the basis for the materialization of the macroeconomic risks, the mitigation of which continues to be the primary task of economic policy to this day.

Firstly, the dissolution of the boundary between commercial and investment banking made it possible for financial conglomerates to form enormous corporations that combine the previously separate financial activities (such as the collection of deposits with insurance and listing securities). The risk effect of the merging of activities is connected with financial stability, which is significant for the entirety of the economy.18 On the one hand, as a consequence of the Gramm-Leach-Bliley Act, such institutions were formed in great numbers that had to be saved by state capital injection in cases of crisis due to their size and role in financial intermediation and their contribution to the national economy. This is the so called 'too big to fail' problem.12 Achieving the classification of 'too big to fail' comes with significant competitive advantage compared to other financial institutions as it allows for carrying out their activity, building market positions and undertaking exaggerated risks in order to increase their profitability in the secure knowledge that the potential costs of risky businesses and losses will always be paid by tax payers. This is the so-called moral hazard problem that produces significant macroeconomic risks. On the other hand, activities with different aims within one institution necessarily lead to conflicts of interest. As Marján expressed if stock analysts were in the same boat as investment bankers, the temptation would be too big to - as it has indeed happened - endorse to investors without a second thought corporations with known problems. Bankers would easily become accomplices of CEOs running away from problems. $\underline{20}$ 
Therefore, instead of solving problems at the micro level, they added up to the macro level due to not having dealt with them.

Secondly - strongly connected to the removal of the barrier from between commercial and investment banking - the originate-to-distribute model formed due to securitization was seriously damaged by the originator's failure to be sufficiently circumspect, and spread more than just good quality mortgages among investors. Due to a relaxation of mortgage lending conditions, increasing numbers of so-called subprime borrowers received mortgages that were then also securitized, resulting in complex derivative securities - the risks of which could not even be assessed by the issuers themselves in some cases. They were sold to investors, hence placing the risks off the balance sheet. As a result of this practice, at first everyone was a winner: debtors received loans, banks issued an increasing number of loans that raised their income, those repackaging securities got their premiums and savers realized significant returns without perceiving risk.21 At the same time, the success of such lending formed a bubble, together with which securitization - after reaching a 'critical mass' - no longer meant the spreading of risk but rather the infection of the whole financial system.

Macroeconomic risks produced as a result of the abovementioned practices highlighted the fact that the micro-level approach to the regulation and supervision of the modern financial system, i.e. individual institutional prudence is insufficient. The micro-level stability of the financial system before the economic crisis concealed the accumulated systemic risks, the forecasting and management of which must be made part of the regulatory and supervisory system. Therefore states, economic integration organizations and various international institutions are making significant efforts globally in order to create suitable institutional frameworks and tools for the prevention, discovery and management of systemic risks. $\underline{22}$

\section{Basic definitions of macroprudential policy}

After having presented the reasons for the spread of macroprudential regulation and supervision (hereinafter referred altogether to as macroprudential policy), we will attempt to define the basic concepts and aims of macroprudential policy. Firstly, the origin of the term 'macro-prudence' must be mentioned briefly, as in spite of the need for macroprudential approach having been brought to the fore by the present economic crisis, its appearance dates back to much earlier.

\subsection{The origin of the term 'macro-prudence'}

Uncovering the exact origin of the term macro-prudence is not an easy task, but academic literature relates its inception to the expert work done at the Bank of International Settlements (hereinafter/henceforth referred to as BIS). Piet Clement demonstrated that - according to BIS archives - the first appearance of the term macro-prudence in an international context was in 1979 at a meeting of the Cooke Committee (the forerunner of the present-day Basel Committee on Banking Supervision, the BCBS), where experts discussed the hidden risks of maturity transformation in international interbank lending. $\underline{23}$ Because this document was an internal publication, the term was not publicized. The first public document that specifically dealt with macroprudential policy was a report by one of BIS's committees (Committee on the Global Financial System).24 It was not by accident that the question of the necessity of macroprudential policy emerged in connection with risks hidden in the derivative markets and the process of securitization. However, 'cyclical euphoria' overshadowed expert proposals - in parallel with the liberalization and deregulation of the financial markets 25 - and up until the beginning of 2000 , the notion of macro-prudence was only rarely used.26 The notion's 'rebirth' is traced back to a speech from September 2000 by Andrew Crockett, head of the Financial Stability Forum.27 Crockett summarized the differences between the macro- and microprudential approaches of regulation and supervision, and expressed his concern that in order to reach financial stability, the macroprudential approach would be needed to be reinforced. In spite of the abovementioned, - apart from a few exceptions $\underline{28}-$ academic journals remained almost indifferent to macroprudential policy, as Figure 1 shows.

Figure 1: Appearances of the term 'macro-prudence' in academic journals based on the EBSCO EconLit database (edited by the author) 


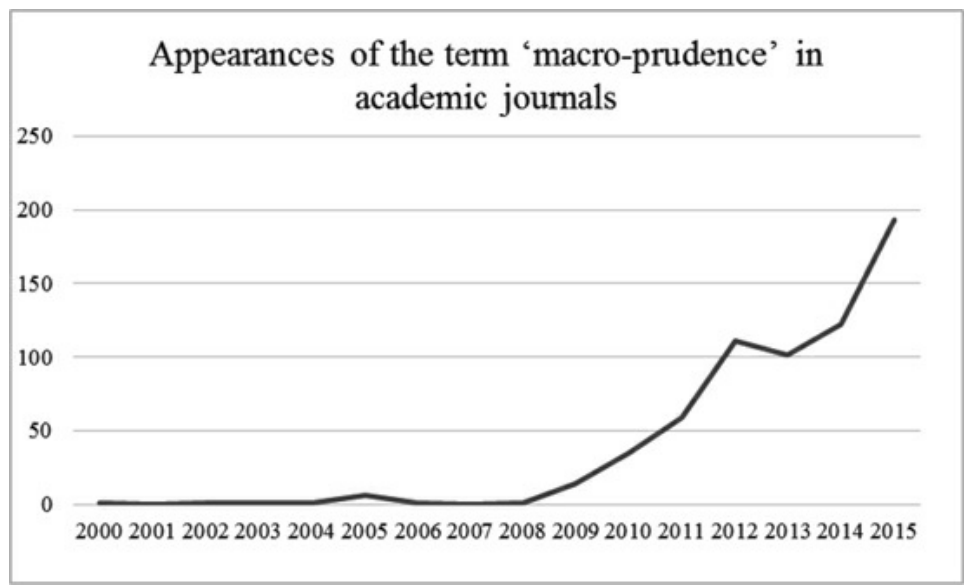

\subsection{The concept and aims of macroprudential policy}

Macroprudential policy can be defined as the primary use of prudential tools to limit systemic risks and assure the stability of the financial system. The central element of the notion of macroprudential policy is the concept of systemic risk itself, which encompasses the decline in the provision of financial services due to the weakening of the whole or part of the financial system in a way that this decline has a potentially profound negative effect on real economy.22 In other words, by way of financial institutions' risk-taking and risk-management practices, systemic risks affect the whole of the financial system and thereby the economy as well, since through shifts in economic conditions they become internal risks for particular market actors. 30

According to academic literature, the rationale for macroprudential intervention can essentially be found in the occurrence of externalities of the financial system stemming from systemic risks.

Firstly, externalities can arise between particular institutions of the financial system. As credit grows, there can be excessive reliance on short-term wholesale funding provided by banks and non-bank financial institutions that exposes the system to liquidity risk. A build-up of exposure to funding and derivative markets also goes hand in hand with the risk of intermediaries becoming 'too interconnected to fail'. These institutions take larger risks - relying on a state lifeline in case of trouble - through which they gain a competitive advantage, yet they also 'poison' other market actors, weaken market discipline and the incentive to appropriately control risk.31 Besides, they do not take into consideration the effect of their own exposure on the whole system of financial services. 32

Secondly, externality can lead to an overexposure of the system to aggregate shocks. A proven correlation exists between credit and asset prices, resulting in widespread leverage and increases the vulnerability of the system against declines in asset prices. Credit booms caused by competitive pressure and capital flow leading to an erosion of lending standards that also increases the financial system's exposure to macro shocks. At the same time, overreliance on short-term wholesale funding exposes the system to crises of confidence. 33

Thirdly, externalities can arise when the financial system amplifies adverse shocks to the economy. 34 This characteristic is referred to as pro-cyclic behavior. The most well-known form of pro-cyclic behavior is the so-called credit crunch phenomenon, when decreasing profitability, increasing costs of external financing and exchange rate devaluation leads to problems of capital adequacy and liquidity, to which banks react by either cutting or in extreme cases, stopping lending. Reduction of lending leads to cuts in investments and employment that also causes serious problems in the real economy. 35 Besides the credit crunch phenomenon, we must also mention the so-called fire sale effect, when multiple institutions start selling illiquid securities, thereby depressing prices, further weakening balance sheets and increasing the cost of credit, applying a negative effect on the real economy. $\underline{36}$

These externalities give rise to three objectives or 'tasks' for macroprudential policy. Macroprudential policy - as an example of financial stability policy - (1) must handle structural or cross-sectoral risks, (2) must increase the resistance and flexibility of the financial system in the face of aggregate systemic shocks, and (3) must decrease the financial system's pro-cyclicality, i.e. the time dimension of risks. Therefore, firstly, the task of macroprudential policy is the handling of structural or cross-sectoral risks through the regulation of the vulnerability stemming from the interconnections of financial intermediaries in the financial system. Secondly, its task is to increase the resilience of the financial system to aggregate systemic shocks by building buffers that absorb their impact and help maintain the ability 
of the financial system to provide credit to the economy. Thirdly, its task is to decrease the inherent pro-cyclicality of the financial system by introducing various capital requirements, provisioning and liquidity regulations, and leverage indicators, i.e. through administrative limits.

The objectives of macroprudential policy can primarily be realized through macroprudential regulation and supervision. Macroprudential regulation means financial regulation that aims to control the social costs associated with excessive balance-sheet shrinkage on the part of multiple financial institutions hit with a common shock.37 The notion of macroprudential supervision refers to the entire process of (1) monitoring and analysis of the financial system as a whole in order to chart vulnerabilities; (2) assessing potential threats to financial stability and deciding to take mitigating action, (3) implementing measures to actually mitigate vulnerabilities, and (4) evaluating these actions in order to ascertain to what extent vulnerabilities have indeed been diminished. $\underline{38}$

Ensuring the stability of the financial system can also be achieved with approaches other than macroprudential policy, which therefore must closely cooperate with other areas of economic policy, since the stability of the economic system can only be maintained through harmonized coordination.

\section{The place of macroprudential policy within the system of economic policies}

Hence, macroprudential policy must cooperate with several other economic policy areas in order to reach its goals. Figure 2 presents the relationship between macroprudential and other policies.

Figure 2: The relationships between macroprudential and other policies (edited by the author)

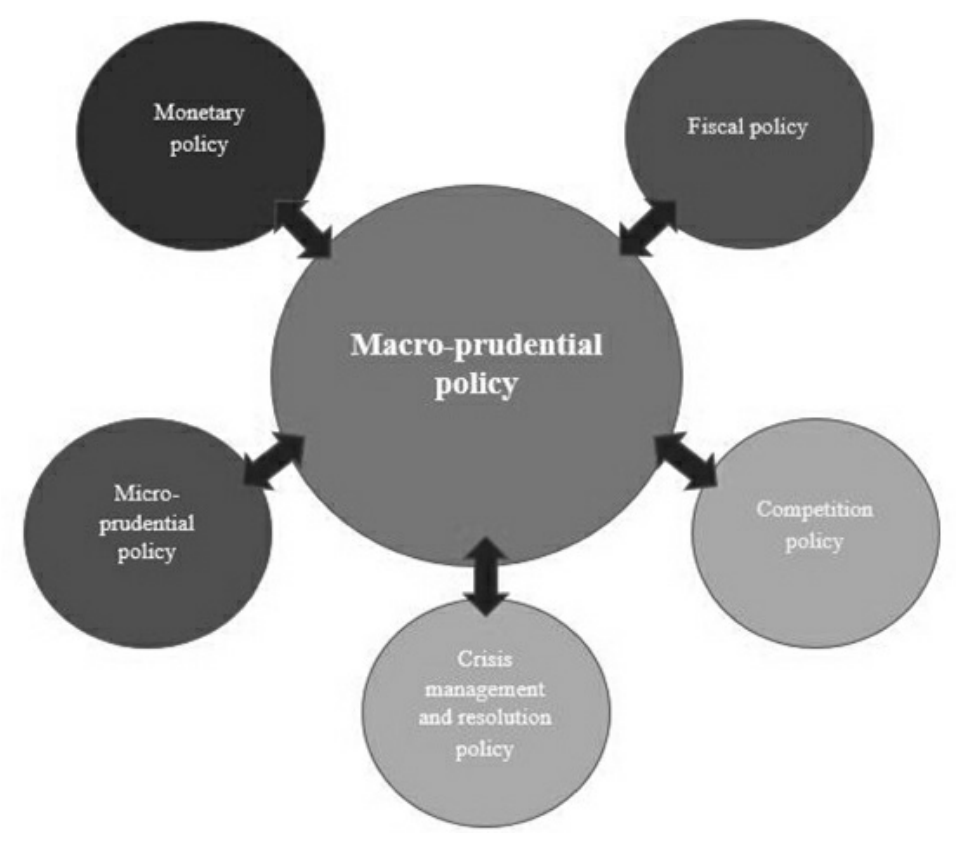

\subsection{The relationship of macroprudential policy and monetary policy}

The most recent financial crisis completely undermined the preceding consensus and showed that price stability does not guarantee financial or macroeconomic stability. 39 Several countries had to deal with dangerous financial instability besides extremely low inflation levels. In order to ensure macroeconomic stability, monetary policy - among others - has to take financial stability objectives into consideration, and because of the strong connections of the two policy areas, central banks also have to play a leading role in the realization of macroprudential policy.

Macroprudential policy and monetary policy supplement each other in a flexible way, which is especially significant when monetary policy itself hits its limitations - as could be seen in the economic crisis of 2008.

On the one hand, - ex ante - well-calibrated and clearly communicated macroprudential policies can limit risks, thereby easing the burden on monetary policy. Macroprudential policy may assist in the controlling of lending and 
thereby affects asset prices - thus decreasing risks stemming from the formation of asset price bubbles - and can ease asset price fluctuations originating from pro-cyclical behavior. Moreover, when macroprudential policies - ex ante constrain risk-taking, they reduce the risk of financial disturbances. $\underline{40}$

On the other hand, macroprudential policy also provides buffers against unexpected shocks, lessening the risk of the monetary policy's running into its own limitation, the $0 \%$ interest rate. At times of recession, macroprudential policy can - ex post - dampen the effect of shocks on lending and the financing of the economy by releasing these buffers, hence supplementing the devices of monetary policy. $\underline{41}$

\subsection{The relationship between macroprudential and fiscal policies}

Adequate fiscal policy plays a significant role in the avoidance of macroeconomic shocks as well as in the handling of existing ones.

Firstly, certain types of tax may contribute to the build-up of systemic risks. Corporate taxes - as several analyses point out $\underline{42}$ - generally increase willingness to development using loans, as opposed to financing from capital. Many countries do not provide tax breaks for those renting property, while providing generous relief for mortgage interest. This can be a source of significant distortion and revenue loss, as households are encouraged to borrow against housing assets, either to invest in non-housing assets or to finance immediate consumption. Such fiscal policy decisions can cause distortions in the financial system that could be avoided through the creation of coordination mechanisms.

Secondly, fiscal policy can have a direct effect on risks in the financial system via taxes, levies and fees. So-called Pigovian taxes $\underline{\underline{3}}$ (such as the bank tax) and so-called financial stability contributions $\underline{4}$ (such as contributions paid into resolution funds) states can influence the behavior of actors in the financial markets and at the same time can create funds - using revenues of market actors - in order to ensure financial stability.

Thirdly, taxes affect asset prices in that a newly introduced tax decreases an asset's price by decreasing the profitability of the asset. Therefore, in periods of prosperity, fiscal policy can be used to prevent the development of asset price bubbles.

\subsection{The relationship of macroprudential and microprudential policies}

One main lesson of the economic crisis has been that although microprudential regulation is necessary, it is not sufficient for a stable operation of the financial system since the latter is much more than the sum of its financial institutions. In order to defend against losses stemming from systemic risks, the institutional approach in itself is not enough; therefore, the policy areas representing two different perspectives must cooperate closely. The comparison of macro- and microprudential policy can be seen in Table 1 .

\section{Table 1: Comparison of macro and microprudential perspectives $\underline{45}$}

\begin{tabular}{|c|c|c|}
\hline \multicolumn{3}{|c|}{ Macro and microprudential perspectives } \\
\hline & $\begin{array}{l}\text { Macroprudential } \\
\text { policy }\end{array}$ & $\begin{array}{l}\text { Microprudential } \\
\text { policy }\end{array}$ \\
\hline Immediate objective & $\begin{array}{l}\text { Limit financial system-wide distress and systemic } \\
\text { risk }\end{array}$ & $\begin{array}{l}\text { Limit individual risks, decreasing threats affecting } \\
\text { individual institutions }\end{array}$ \\
\hline Ultimate objective & Avoid output costs & Consumer protection \\
\hline Type of risk & $\begin{array}{l}\text { (Partly) Endogenous: result of the common } \\
\text { behavior of individual institutions }\end{array}$ & $\begin{array}{l}\text { Exogenous: they can be regarded as a given in } \\
\text { relation to individual institutions }\end{array}$ \\
\hline $\begin{array}{l}\text { Correlations and common } \\
\text { exposures across institutions }\end{array}$ & Important & Irrelevant \\
\hline Calibration of prudential controls & In terms of system-wide risks: top-down & $\begin{array}{l}\text { In terms of risks for individual institutions: bottom- } \\
\qquad u p\end{array}$ \\
\hline
\end{tabular}


It can be seen from the comparison that while microprudential policy contributes to the stability of the financial market through the prevention and discovery of institutional risks, macroprudential policy does so via the prevention and discovery of systemic risks. Therefore sharing information and the joint analysis of risks, as well as tight communication are necessary to realize the supplementary benefits. Besides close cooperation, there must also be mechanisms in place that are able to resolve conflicts arising from differing perspectives and objectives - mainly occurring at times of economic shock. Regardless of their distinct approaches, macroprudential and microprudential policies both deliver their effects through the same transmission mechanism. During periods of 'good times', the microprudential authority probably agrees with the formation of buffers being a prudent behavior, even if the ratio of credit default is low and profitability is high. However, in 'bad times', tension may increase between the two policy areas, as the macroprudential authority - in order to break pro-cyclicality - would like to ease regulatory conditions in order to avoid a credit crunch and a fire sale, while the micro-prudential authority would tighten requirements to protect depositors and investors. $46 \mathrm{In}$ order to resolve conflicts, it needs to be clarified which perspective should have priority at which times.

\subsection{The relationship of macroprudential policy, crisis management and resolution policy}

Crisis management and resolution policy also supplement macroprudential policy. Macroprudential policy averts risks threatening financial stability as a 'first line of defense' by identifying and managing them. However, in practice all threats cannot be averted, therefore, the macroprudential authority increases resilience of the financial system as a 'second line of defense'. At the inception of a crisis, when the system is not able to neutralize shocks, crisis management and resolution are the final, 'third line of defense' for maintaining financial stability. 47 The establishment of crisis management and resolution systems, recognizing the unsustainability of national bailout actions, $\underline{48}$ aims at the regulated removal of a failing financial institution from the market in order to maintain financial stability. An effective and credible crisis management and resolution system may support the realization of the objectives of macroprudential policy by reinforcing market discipline. $\underline{49}$

\subsection{The relationship between macroprudential and competitive policies}

The freedom of economic competition originates from the theoretical consensus that competition ensures cost efficiency, the ongoing improvement of the quality and standards of goods and services: all in all, greater efficiency. When carrying out financial activity, intensive competition often incentivizes financial institutions to take excessive risks and grow too fast, and mergers can result in institutions too large in size, carrying in them systemic risks. 50 Because of this, tension may arise between the objectives of competition policy and financial stability: the assurance of fair competition may conflict with ensuring financial stability. In order to avoid tension, it is necessary to establish that in relation to the financial sector, the scrutiny of economic competition must be supplemented with a macroprudential perspective. In order to achieve this, certain elements of traditional competition law enforcement (such as authorization, investigation of effective control, merger approval) have been assigned to the macroprudential supervisory authorities in several countries. Other countries implemented strict coordination and consultation mechanisms between the two policy areas and have incorporated financial stability and as a secondary aim into the mission statement of competition authorities.

\section{Summary}

The global economic crisis has brought into sharp focus the fact that as a result of financial globalization - which primarily manifests itself in the form of the liberalization and deregulation of the financial system - financial institutions are intricately intertwined, leading to the appearance at the global level of instability in the financial system - the so called poisoning effect. Even before the symbolic start of the crisis (the bankruptcy of Lehman Brothers), Rajan had already pointed out that the international financial system, the capital and money markets had built up new risks that were not seen by anybody, could not be assessed but still they existed.51 Macroprudential policy specifically aims to forecast, identify and manage these systemic risks pent up in the financial system. Macroprudential policy has to handle structural risks, increase the resilience and flexibility of the financial system against shocks, and decrease the financial system's pro-cyclicality, i.e. the time dimension of risks. Ensuring financial stability - and thereby economic stability cannot be achieved by macroprudential policy alone; therefore, it is essential that it may operate in close cooperation with other economic policy areas. 


\section{References}

1 The scope of this study does not include the presentation of the organizational framework of macroprudential regulation and supervision, or the analysis and evaluation of its toolset.

2 It is interesting to note that the first bubble crisis broke out in the Netherlands in 1637 (the so-called Tulpenwoerde, meaning tulip mania). Because of speculation, the price of tulip bulbs increased unbelievably over a few years, until the bubble burst and a bulb worth up to the price of a ship one day, regained its original value the next day. Essentially the same happened at the inception of the 2001 dotcom and the 2007 asset price bubbles. See also: Christian C. Day, Paper Conspiracies and the End of all Good Order: Perceptions and Speculation in Early Capital Markets, 1 Entrepreneurial Business Law Journal 283, 322 (2006).

$\underline{3}$ Rising and declining periods are referred to as cycles. The four most significant types are the Kitchin, Juglar, Kondratyev, and Braudel cycles. The Kitchin cycle, which is also called the inventory cycle, is the shortest one, describing around the fluctuation of the economy over about 3 to 5 years. The Juglar cycle, also known as the fixed-investment cycle, lasts for 7-11 years. The Kondratyev cycle encompasses 50-60 years, consisting of one rising and one declining period. The longest period, 100-200 years, is described by the Braudel cycle. Over this time frame, even practically immobile structures change. We must note that due to the acceleration of the world, the peaks and troughs have moved closer to one another: that is, cycles of 200 years have become shorter, even as much as half the previous length. On the causes of cycles see: András Bródy, A ciklus oka és hatása, 52 Közgazdasági Szemle 903, 914 (2007).

4 Luc Laeven, Fabian Valencia, Systemic Banking Crises: A New Database, IMF Working Paper, No. 224 (2008). 10.5089/9781451870824.001

5 Banking Act of 1933, https://ia802702.us.archive.org/7/items/FullTextTheGlasssteagallActA.k.a.TheBankingActOf1933/1933 01248.pdf (accessed 11 December 2015).

6 See Vincent P. Carosso, Investment Banking in America: A History (Harvard University Press, 1970).

Z See further Howard H. Preston, The Banking Act of 1933, 23 Am. Econ. Rev. 585, 607 (1993).

8 Sándor Ligeti, Márta Sulyok-Pap (eds.), Banküzemtan (Tanszék Pénzügyi Tanácsadó és Szolgáltató Kft. 1998),

2 See William D. Jackson, Glass-Steagall Act: Commercial vs. Investment Banking, 26 (Congressional Research Service,1987).

10 'Securitization' can be defined as a process of separation, restructuring and transportation of a loan portfolio having adequate credit enhancement to investors. 'Securitization' was first used by Salomon Brothers in the public stock issuance for Bank of America in 1977. See Leon T. Kendall, Michael J. Fishman (eds.), A Primer on Securitization (MIT Press, 1996), 31.

11 Júlia Király, Márton Nagy \& E. Viktor Szabó, Egy különleges eseménysorozat elemzése - a másodrendű jelzáloghitelpiaci válság és (hazai) következményei, 55 Közgazdasági Szemle 573, 621 (2008), 584.

12 James R. Barth, R. Dan Brumbaugh \& James A. Wilcox, Source Policy Watch: The Repeal of Glass-Steagall and the Advent of Broad Banking, 14 J. Econ. Perspect., 191, 204 (2000), 196. 10.1257/jep.14.2.191

13 See also: Zsuzsánna Biedermann, The History of the American Financial Regulation, 57 Public Financ. Quart. 313, 331 (2012).

14 Wolfgang H. Reinicke, Banking, Politics, and Global Finance: American Commercial Banks and Regulatory Change, 1980-1990, 114. (Edward Elgar, 1995).

15 See also: Jill M. Hendrickson, The Long and Bumpy Road to Glass-Steagall Reform: A Historical and Evolutionary Analysis of Banking Legislation, 60 A. J. Econ. Sociol. 849, 879 (2001). 10.1111/1536-7150.00126

16 See also the Hungarian literature regarding this subject: György László Asztalos, The correlation between the financial crisis and the crisis of the financial institutions, 54 Public Financ. Quart. 369, 406 (2009); József Móczár, Anatomy and lessons of the global financial crisis, 55 Public Financ. Quart. 753, 775 (2010); Miklós Losoncz, The global financial crisis and the European Union, 55 Public Financ. Quart. 792, 808 (2010). See also in foreign specialized literature: Joseph E. Stiglitz, The current economic crisis and lessons for economic theory, 35 Eastern Economic Journal 281, 296 (2009); Mark Jickling, (2010): Causes of the financial crisis (Congressional Research Service, 2010); Jeffrey M. Lipchaw, 
The Financial Crisis of 2008-2009: Capitalism Didn't Fail, but the Metaphors Got a 'C', 95 Minn. Law Rev. 1532, 1567 (2011). 10.1057/eej.2009.24

17 The expression comes from Raghuram G. Rajan, who uses it to describe how faith in Draconian regulation is strongest at the bottom of the cycle - when there is little need for participants to be regulated. By contrast, the misconception that markets will take care of themselves is most widespread at the top of the cycle - the point of maximum danger for the system. In case of growth, at the highest point of expansion, when the chance of market actors taking exaggerated risks is highest, everyone trusts the self-regulatory mechanism of the market. See Raghuram G. Rajan, The Credit Crisis and Cycle-Proof Regulation, 91 Fed Reserve Bank St. 397, 402 (2009), 400.

18 Borbála Szüle, A pénzügyi konglomerátumok létrejöttének kockázati hatásai, 53 Közgazdasági Szemle 661, 680 (2006), 662.

19 According to most sources, the source of the expression can be traced to Senator McKinney, who used it at a Congress hearing in 1984. See Hearings before the Subcommittee on Financial Institutions Supervision, Regulation and Insurance of the Committee on Banking, Finance and Urban Affairs House of Representatives, Ninety-Eight Congress, Second Session, 1984, 89. https://fraser.stlouisfed.org/docs/historical/house/house_cinb1984.pdf (accessed 11 December 2015).The first appearance of this terminology in literature is in the works of Walter Adams and James W. Brock. See Walter Adams, James W. Brock, Corporate Size and the Bailout Factor, 21 J. Econ. Issues 61, 85 (1987).

20 Attila Marján, Az európai pénzügyi szolgáltatási szektor és a gazdasági és monetáris unió, http://phd.lib.unicorvinus.hu/126/1/marjan attila.pdf (accessed 11 December 2015), 55.

21 Biedermann, supra n. 13, at 343 .

22 See: A Financial Stability Forum: Report of the Financial Stability Forum on Addressing Procyclicality in the Financial System (2009), http://www.financialstabilityboard.org/wp-content/uploads/r 0904a.pdf (accessed 11 December 2015). European Union: The High Level Group on Financial Supervision is the EU: De Larosiere Report (2009), http://ec.europa.eu/internal market/finances/docs/de larosiere report en.pdf (accessed 11 December 2015). A G20: G20 Working Group 1 Enhancing Sound Regulation and Strengthening Transparency (2009), http://rbidocs.rbi.org.in/rdocs/PublicationReport/Pdfs/20 010409.pdf (accessed 11 December 2015).

23 Piet Clement, The term 'macroprudential': origins and evolution, BIS Quarterly Review, 59, 67 (2010), 59-60.

24 Recent innovations in international banking (Cross Report), CGFS Publications No 1. (1986), http://www.bis.org/publ/ecsc01c.pdf (accessed 11 December 2015), 233-244.

25 Liberalization essentially means restoring the conditions of the market economy in areas where state intervention has reached significant levels. Deregulation means the removal of regulations on various financial sectors, financial services, interoperability of sectors with one another; generally, it means the reduction of limiting legislation.

$\underline{26}$ We must emphasize from this period that the concept itself escaped the circle of 'central bankers' and the IMF also started to use it, initially in connection with the crisis in South East Asia. See: Key Aspects of a Framework for a Sound Financial System (1998), http://www.imf.org/external/pubs/ft/wefs/toward/pdf/file03.pdf (accessed 11 December 2015), 13.

27 Andrew D. Crockett, Marrying the micro- and macroprudential dimensions of financial stability, http://www.bis.org/speeches/sp000921.htm (accessed 11 December 2015).

28 See: Ágnes Lublóy, Rendszerkockázat a bankszektorban, 2 Hitelintézeti Szemle 70, 90 (2003); Jean-Charles Rochet, A Framework for Macroprudential Banking Regulation, 12 Revista de Economia 6, 16 (2005), 6-16.; Claudio Borio, Monetary and Financial Stability: So Close and Yet So Far? 192 National Institute Economic Review 84, 101 (2005). 10.1177/002795010519

22 On the academic literature approach to the notion of systemic risk see also: Lubóy, supra n. 13, at 77-81.

200109

30 Katalin Mérö, A bankszabályozás kihivásai és változásai a pénzügyi-gazdasági válság hatására, 133 in Pál Valetiny, Ferenc László Kiss \& Csongor István Nagy (eds.), Verseny és szabályozás 2011 (MTA KRTK Közgazdaság-tudományi Intézet, 2012).

31 See: Viral Acharya, Matthew Richardson (eds.), Restoring Financial Stability: How to Repair a Failed System (New York University Stern School of Business, 2009). 10.1002/9781118258163 
32 Anikó Szombati, A makroprudenciális felügyeleti hatáskör Magyarországon, 132 in Lentner Csaba (ed.), Bank menedzsment. Bankszabályozás - pénzügyi fogyasztóvédelem (Nemzeti Közszolgálati és Tankönyvkiadó, 2013).

33 See Gianni De Nicolò, Giovanni Favara \& Lev Ratnovski, Externalities and Macroprudential Policy, in IMF Staff Discussion Note, No. 5. (2012). 10.2139/ssrn.2083302

34 Samuel G. Hanson, Anil K. Kashyap \& Jeremy C. Stein, A Macroprudential Approach to Financial Regulation, 25 J. Econ. Perspect. 3, 28 (2011). 10.1257/jep.25.1.3

35 Ádám Balog, György Matolcsy, Márton Nagy \& Balázs Vonnák, Credit crunch Magyarországon 2009-2013 között: egy hiteltelen korszak vége? 13 Hitelintézeti Szemle, 11, 34 (2014), 11.

36 Douglas W. Diamond, Raghuram G. Rajan, Fear of Fire Sales and the Credit Freeze, NBER Working Paper, No. 14925. (2009). 10.3386/w14925

37 Hanson, Kashyap \& Stein, supra n. 34, at 5. 10.1257/jep.25.1.3

38 Towards a more stable financial system: Macroprudential supervision at DNB, 2010, De Nederlandsche Bank, http://www.dnb.nl/en/binaries/Towards $\% 20 \mathrm{a} \% 20$ more $\% 20$ stable $\% 20$ financial\%20system tcm $47-236522 . p d f$ (accessed 11 December 2015), 12.

39 Pamfili Antipa, Julien Matheron, Interactions between monetary and macroprudential policies, 18 Financial Stability Review 225, 239 (2014), 226.

40 Stijn Claessens (et al.), The Interaction of Monetary and Macroprudential Policies (IMF 2013), 10-11.

$\underline{41}$ Ibid. 11.

$\underline{42}$ Ruud A. de Mooij, Tax Biases to Debt Finance: Assessing the Problem, Finding Solutions, IMF Staff Discussion Note, No. 11. (2011). 10.5089/9781463935139.006

$\underline{43}$ Taxes with which the state attempts to balance the negative social effects of an activity by taxing those entities who engage in those activities.

44 See: A Fair and Substantial Contribution by the Financial Sector, Final Report to the G20, 2010, IMF. https://www.imf.org/external/np/g20/pdf/062710b.pdf (accessed 11 December 2015).

45 Source: Claudio Borio, Towards a macroprudential framework for financial supervision and regulation? BIS Working Paper, No. 128. (2003), 2.

46 Jacek Osiński, Katharine Seal \& Lex Hoogduin, Macroprudential and Microprudential Policies: Toward Cohabitation, IMF Staff Discussion Note. No. 5. (2013), 9-10. 10.5089/9781484369999.006

47 See also: Towards a more stable financial system: Macroprudential supervision at DNB, 12-14.

$\underline{48}$ Financial rescue operations incentivize risk taking, weaken national budgets and distort competition. See: Thomas F. Huertas, A szanálás reformja, 12 Hitelintézeti Szemle 86, 101 (2014), 88-89.

49 Claessens, supra n. 40, at 14-15.

50 See Xavier Vives, Competition policy in banking, 27 Oxford Rev. Econ. Pol. 479, 497 (2011) and Lev Ratnovski, Competition Policy for Modern Banks, IMF Working Paper No. 126. (2013), 8. 10.1093/oxrep/grr021, 10.2139/ssrn.2270288

51 See Raghuram G. Rajan, Has Financial Globalization Made the World Riskier? NBER Working Paper, No. 11728 (2005). 